\title{
NEW RUGOSOCHONETIDAE (BRACHIOPODA) FROM THE UPPER BASHKIRIAN AND MOSCOVIAN OF THE CANTABRIAN MOUNTAINS (N SPAIN)
}

\author{
M. Luisa MARTÍNEZ CHACÓN ${ }^{l}$ and Cor F. WINKLER PRINS \\ ' Departamento de Geología, Universidad de Oviedo, c/ Jesús Arias de Velasco s/n, E 33005 Oviedo \\ (Spain); e-mail: mmchacon@asturias.geol.uniovi.es \\ 2 Nationaal Natuurhistorisch Museum, Postbus 9517, NL 2300 RA Leiden (The Netherlands); e-mail: \\ winkler@naturalis.nnm.nl
}

Martínez Chacón, M.L. and Winkler Prins, C.F. 2000. New Rugosochonetidae (Brachiopoda) from the upper Bashkirian and Moscovian of the Cantabrian Mountains (N Spain). [Nuevos Rugosochonetidae (Brachiopoda) del Bashkiriense superior y Moscoviense de la Cordillera Cantábrica (N de España).] Revista Española de Paleontología, 15(2), 219-232. ISSN 0213-6937.

\begin{abstract}
The Rugosochonetidae are widely spread in the Carboniferous of the Cantabrian Mountains and they have often been described or cited by previous authors. In this paper we present a study of the Rugosochonetidae found in upper Bashkirian and Moscovian (Pennsylvanian) rocks from the Cantabrian Mountains. The diagnosis of the family is modified in order to accommodate forms with a typical rugosochonetid ornamentation but without a dorsal median septum, which are included in the new genus Riosanetes, type genus of the new subfamily Riosanetinae. The new species Riosanetes fernandezi (type species of the new genus), Neochonetes (Neochonetes) villamaninensis, $N$. (N.) saenzi, $N$. (N.) asturianus, and $N$. (N.) babianus are described. The latter species is based on material previously described by us as Neochonetes acanthophorus (Girty, 1934).
\end{abstract}

Keywords: Brachiopods, chonetids, Rugosochonetidae, Bashkirian, Moscovian, Carboniferous, Cantabrian Mountains, Spain.

\section{RESUMEN}

Los chonétidos de la familia Rugosochonetidae están ampliamente difundidos en el Carbonífero de la Cordillera Cantábrica, por lo que han sido descritos o citados frecuentemente en trabajos previos de distintos autores. El presente trabajo se ocupa del estudio de una parte de los rugosochonétidos hallados en rocas del Bashkiriense superior y Moscoviense (Carbonífero superior, Pensilvaniense) de la Cordillera Cantábrica. Este estudio nos ha llevado a modificar la diagnosis de la familia Rugosochonetidae, fundamentalmente para que puedan incluirse en ella los chonétidos con exterior típico para la familia pero sin septo medio dorsal. Para este grupo de Rugosochonetidae se establece la nueva subfamilia Riosanetinae, con el nuevo género Riosanetes como género tipo. También se describe la nueva especie Riosanetes fernandezi, especie tipo del género, así como las especies Neochonetes (Neochonetes) villamaninensis, N. (N.) saenzi, N. (N.) asturianus y $N$. (N.) babianus también nuevas. Esta ultima especie se basa sobre material descrito previamente por nosotros como Neochonetes acanthophorus (Girty, 1934).

Palabras clave: Braquiópodos, chonétidos, Rugosochonetidae, Bashkiriense, Moscoviense, Carbonífero, Cordillera Cantábrica, España.

\section{INTRODUCTION}

The family Rugosochonetidae is with its 50 odd genera the largest family of the superfamily Chonetoidea. The most important of the nine subfamilies included in the Rugosochonetidae by Racheboeuf (1998) is the subfamily Rugosochonetinae with its global distribution and ranging throughout the Carboniferous and Permian. The Rugosochonetidae are well represented in the Carboniferous of the Cantabrian Mts, although at most localities they are few in number of specimens; occasionally, however, they dominate a fauna. In strata of late Bashkirian and Moscovian age, representatives of the following genera were found sofar: Chonetinella, 


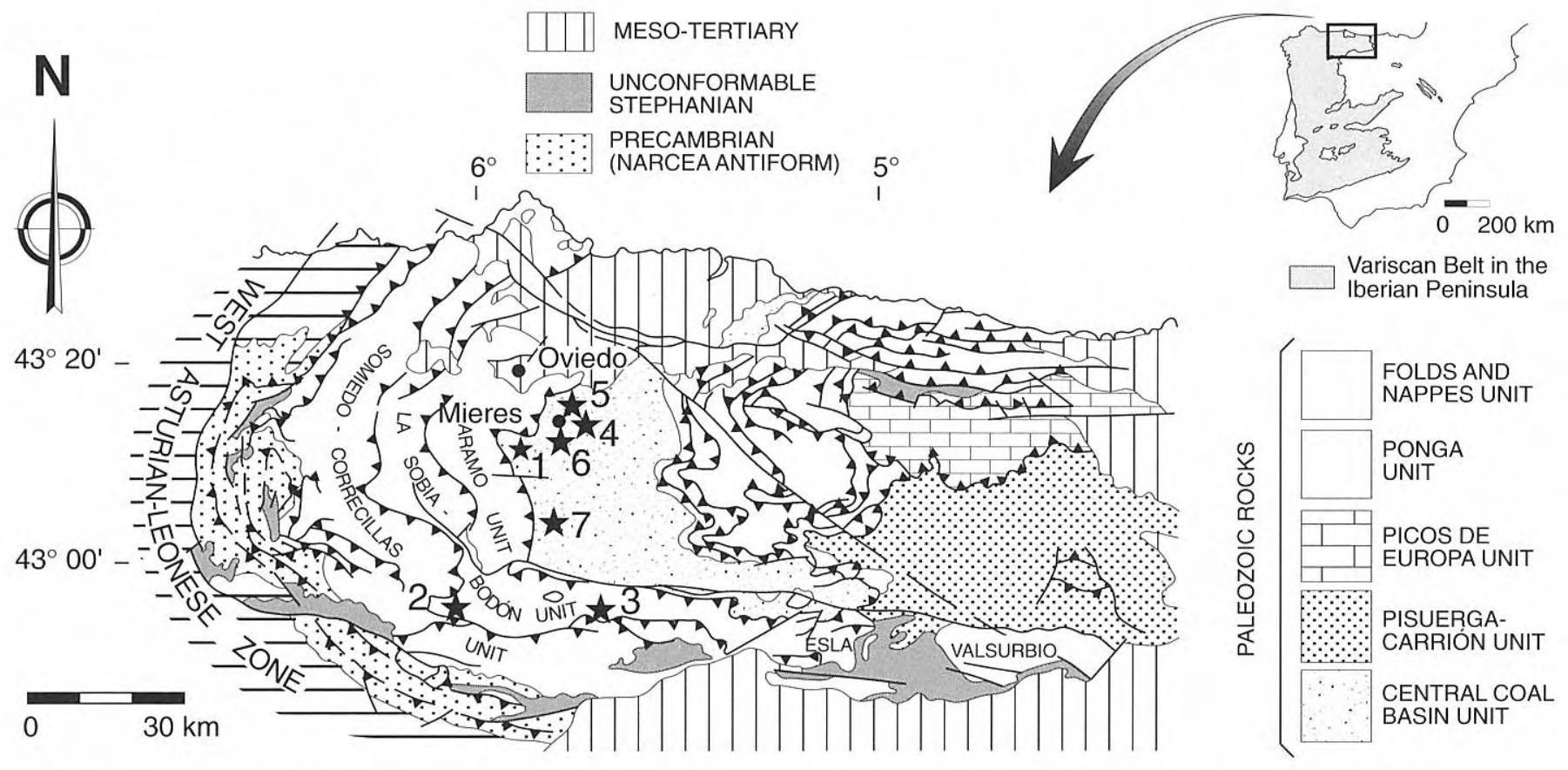

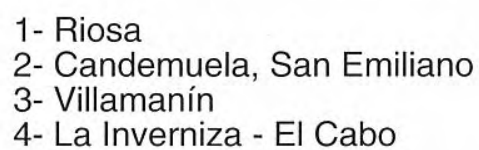

1- Riosa

3- Villamanín

4- La Inverniza - El Cabo

\section{5- La Matinada - Los Nadales}

6- S Mieres

7- Navidiello Hill

Figure 1. Simplified geological map of the Cantabrian Zone (after Pérez Estaún et al., 1988), showing the collecting localities.

Isochonetes?, Lissochonetes?, Neochonetes, Rugosochonetes, and Sokolskya (Barrois, 1882; Delépine, 1943; Winkler Prins, 1968, 1983; van Amerom et al., 1970; Martínez Chacón, 1979, 1990; Wagner et al., 1983; Wagner and Winkler Prins, 1985; Luque et al., 1985; Río García and Martínez Chacón, 1988; Villa et al., 1988; Río García, 1993).

The material described has been collected from upper Baskirian and Moscovian rocks at various localities in Asturias and León (Fig. 1), situated in the Sobia-Bodón Unit (Candemuela Member of the San Emiliano Formation and Villamanín Beds), and in the Central Coal Basin Unit (Canales Formation, and Generalas and San Antonio Beds). The word "Beds" as applied to the Central Coal Basin is used here as a translation of the Spanish word "Paquetes", used by previous authors as an informal lithostratigraphic unit in that area.

Besides, the new species Neochonetes babianus is introduced for material from the La Majua Member of the San Emiliano Formation and from the Cuera Limestone previously described by us as Neochonetes acanthophorus (Girty, 1934).

The specimens are deposited in the Geology Department of the University of Oviedo (numbers prefixed DPO) and the National Museum of Natural History of The Netherlands at Leiden (numbers prefixed RGM).

\section{Emended diagnosis}

Shell small to big, costate, costellate, capillate, smooth, or lamellose, plano- to concavo-convex; ventral sulcus absent or variably developed, with a corresponding dorsal fold; spines orthomorph, oblique to perpendicular, symmetrically placed; pseudodeltidium and chilidium normally present. Ventral median septum variably developed, always high in its posterior part. Dorsal interior with a large median septum, except in the new subfamily Riosanetinae, in which it is absent; without accessory septa; anderidia always well developed, anteriorly moderately divergent; cardinal process tetralobed externally and bilobed internally, anteriorly delimited by a cardinal process pit.

Subfamilies included: See Racheboeuf (1998); and Riosanetinae subfam. nov.

\section{Discussion}

We have modified the family diagnosis, as developed by Archbold (1982a), Martínez Chacón (1990) and Racheboeuf (1998), to accommodate the new subfamily Riosanetinae without a dorsal median septum, also, to add the costellate ornamentation (in the sense of Williams and Brunton, 1997: shell radially ornamented by costae and costellae; costella is a radial ridge on external surface of shell, which originates later than costae by bifurcation of existing costae or costellae or by intercalation between earlier formed ribs; see also Racheboeuf, 1998), which is very frequent in representatives of this family. 


\section{Subfamily Rugosochonetinae Muir-Wood, 1962}

\section{Diagnosis}

Rugosochonetidae with a costate, costellate or capillate external ornamentation; ventral sulcus absent or variably developed, dorsal fold may be present; orthomorph spines normally oblique forming a low to moderate angle with the hinge. Dorsal interior with high median septum; brachial ridges normally well developed.

Genera included: See Racheboeuf (1998).

\section{Neochonetes Muir-Wood, 1962}

Type species: Chonetes dominus King, 1938; by original designation.

\section{Diagnosis}

Small to large rugosochonetids with a weakly to moderately concavo-convex shell, external radial ornamentation costellate, median sulcus weak to strongly developed, orthomorph spines forming a low to moderate angle with the hinge. Ventral interior with prominent median septum; parallel vascular ridges elevated. Dorsal interior with high median septum and brachial ridges; inner socket riges well developed; outer socket ridges may be present.

\section{Discussion}

In previous papers by one of us (Martínez Chacón, $1979,1990)$, the difficulty of separating the genera Rugosochonetes Sokolskaja, 1950 and Neochonetes has been discussed, and the Bashkirian and Moscovian species from the Cantabrian Mountains were attributed to Rugosochonetes, since the criteria to differentiate the two genera were not clear and Rugosochonetes has priority. In the present paper we use as criteria to differentiate between the two genera the development of a pair of strong, parallel vascular ridges in the interior of the ventral valve of Neochonetes, which are absent or very weakly developed in Rugosochonetes; although, as already observed, the degree of development of the vascular ridges depends on the age of the individual, and their presence has been mentioned in species included in both genera (Martínez Chacón, 1990: 96). Therefore, if one admits these criteria as distinctive between both genera (as indicated by Archbold, 1981 and Racheboeuf, 1998), some species with strong vascular ridges have to be excluded from Rugosochonetes, e.g. R. hindi MuirWood, 1962 and $R$. distinctus Afanasjeva, 1976.

\section{Neochonetes (Neochonetes) Muir-Wood, 1962}

\section{Discussion}

The subgenus Neochonetes (Sommeriella) Archbold, 1982b [= N. (Sommeria) Archbold, 1981] was established for forms with an interior like $N$. (Neochonetes) and an exterior with a well developed ventral sulcus and dorsal fold, a more convex ventral valve, cardinal spines forming an angle of $40-45^{\circ}$ with the hinge and maximum width

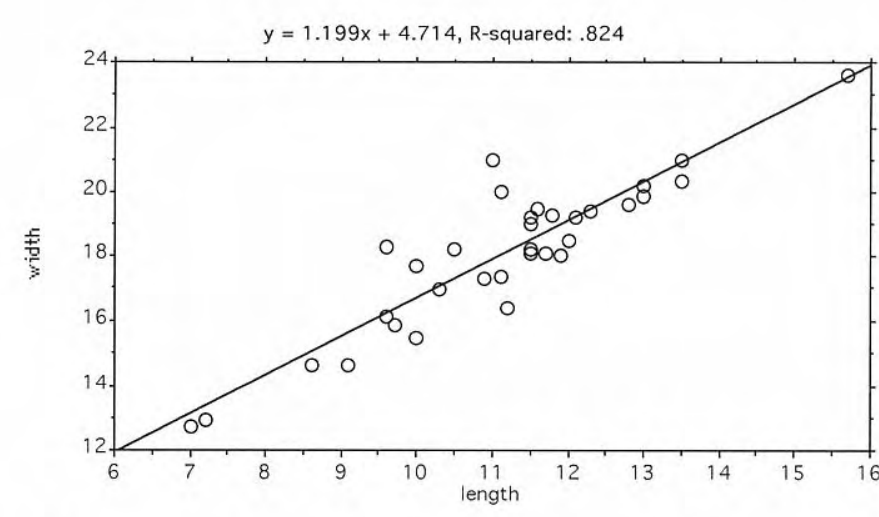

Figure 2. Length-width diagram of Neochonetes (Neochonetes) villamaninensis $\mathrm{sp}$. nov.

situated anterior of the hinge. The Neochonetes species from the upper Bashkirian and Moscovian of the Cantabrian Mts are included in the subgenus $N$. (Neochonetes).

Archbold (1981) described two lineages (stocks) within the subgenus Neochonetes (Neochonetes), one based on $N$. (N.) granulifer (Owen, 1852) and including a.o. the type species Chonetes dominus, the other based on $N$. (N.) carboniferus (Keyserling, 1846) and including a.o. Neochonetes acanthophorus of Winkler Prins (1968). Whilst studying the differences between both groups, we found that in the first group the costulation is more weakly developed, the costulae often becoming obsolete towards the anterior margin. Since Archbold (1981: 111) did not list Neochonetes acanthophorus (Girty, 1934) with either stock, we studied the description of Chonetes granulifer var. armatus Girty, 1911 by Dunbar and Condra, 1932 more carefully and realised that its ornamentation was quite different from our Spanish material and that it belonged to the other group, thus forcing us to create a new species for our Spanish material: $N$. (N.) babianus sp. nov. (see below). Our new species $N$. (N.) villamaninensis and $N$. (N.) saenzi belong in our view to the lineage of $N$. (N.) granulifer, whilst $N$. $(N$.) asturianus and $N$. (N.) babianus belong to the lineage of $N$. (N.) carboniferus.

\section{Neochonetes (Neochonetes) villamaninensis sp. nov. \\ Figs. 2-3}

1983 Rugosochonetes acutus (Demanet, 1938); Winkler Prins, in Wagner et al., fig. 17.

1988 Rugosochonetes n. sp. 1; Villa et al., 339.

Derivatio nominis: The species is named after Villamanín (León), the area from which the material originates.

\section{Locus typicus and stratum typicum}

Railway cutting S of Villanueva de la Tercia (León), at 2-3 m S of km 48 (Fig. 1) (2-3 m above a bed with Diplocraterion). Sandstone layer in the Villamanín Beds of Early Moscovian (late Vereisky) age (Moore et al., 1971; Wagner et al., 1983, figs. 13-17; Villa et al., 1988). 


\section{Material}

Holotype, DPO 38058, internal moulds of ventral and dorsal valves united at the hinge (Fig. 3a) and many other specimens from the type locality and horizon (DPO 3805938080, 38095-38107; RGM 292504-292508, $292517-$ 292578), some with the shell preserved but the majority are external or internal moulds of one or the other valve.

Some 30 specimens, largely moulds but again some with the shell preserved (DPO 38081-38094), from sample T296, W of Candemuela (León), mudstone $100 \mathrm{~m}$ below the top of the Candemuela Member of the San Emiliano Formation (Carballeira et al., 1985), Early Moscovian in age.

\section{Diagnosis}

Neochonetes (Neochonetes) of the lineage of $N$. (N.) granulifer with a transverse shell of rounded subrectangular shape, hinge line equal to the greatest width or nearly so; sulcus inappreciable; flat to very weakly concave dorsal valve; ornamentation of weak costae and costulae, 5-6 per $\mathrm{mm}$ at the anterior margin. Near the internal border of the ventral valve the tubercles are numerous and form a kind of rim.

\section{Description}

Shell of small to medium size $[\mathrm{L}=7.0-15.7 \mathrm{~mm}$ (medium 11.1), $\mathrm{W}=12.7-23.6 \mathrm{~mm}$ (medium 18.0); dimensions of holotype: $\mathrm{L}=11.7 \mathrm{~mm}, \mathrm{Ld}=10.8 \mathrm{~mm}, \mathrm{~W}=$ $18.0 \mathrm{~mm}$; Fig. 2], plano-convex to very weakly concavoconvex, transverse $(\mathrm{L} / \mathrm{W}=\mathrm{c}$. 0.6), of rounded subrectangular shape, with rounded cardinal extremities and the maximum width at the hinge or just in front of it. No sulcus or fold.

Ventral valve weakly and uniformly convex, with umbo hardly protruding. On both sides of the umbo at least 7 spine bases, the farthest away forming an angle of $50-60^{\circ}$ with the hinge. Costellate ornamentation with weak, fine costae and costellae, partly disappearing towards the front, with a density of 5-6 per mm; they are absent on the ears; on the anterior third of the valve growth lamellae appear which are densely stacked near the border.

Dorsal valve practically flat with a similar ornamentation.

Ventral valve interior with a very high median septum in its posterior part between the adductor scars, continuing in front of them as a low ridge at least to mid length but occasionally reaching the anterior margin. Adductor scars small and oval, clearly impressed; the diductor scars are large flabelliform and poorly defined, they can be recognised by the absence of tubercles. In front of the adductors originate a pair of strong vascular ridges, parallel to the median septum, which continue almost to the anterior margin. The internal surface, apart from the muscle scars, is covered with radially arranged rows of tubercles; these are stronger in the posterolateral regions and are densely packed near the front, forming an elevated rim.

Interior of dorsal valve with bilobed cardinal process (externally tetralobate), separated from the median septum by a cardinal process pit. The septum is strong and rather long, more than half the valve length; at its anterior end normally two parallel rows of 2-3 elevated, thick tubercles occur. Anderidia short, finer and lower than the median septum, diverging at an angle of $30-45^{\circ}$. Adductor scars poorly defined. Inner socket ridges elevated, forming an angle of $20^{\circ}$ with the hinge; outer socket ridges also developed. Brachial ridges prominent, with stronger tubercles than the remainder of the valve. Internal surface, apart from the posterior central part, covered with radially arranged rows of tubercles.

\section{Comparison}

The new species resembles the type species in its shape, dimensions and internal characteristics; it is differentiated from it by its less convex ventral valve and flat dorsal valve.

From Rugosochonetes acutus (Demanet, in Demanet and van Straelen, 1938), which can be externally rather similar (see also Winkler Prins, 1968) and to which part of the material was originally referred by one of us (C.F.W.P.), it is distinguished by its stronger developed internal structures and the flatter dorsal valve.

A comparison with the new species $N$. (N.) saenzi, $N$. (N.) asturianus and $N$. (N.) babianus follows below at the descriptions of those species.

\section{Distribution}

The species is only known from the upper part of the Candamuela Member of the San Emiliano Formation and the Villamanín Beds, both of Vereisky age.

\section{Neochonetes (Neochonetes) saenzi sp. nov. Figs. 4-5}

\pm 1985 Rugosochonetes cf. dalmanoides; Luque et al., 294 (pars).

Derivatio nominis: The species is dedicated to José Antonio Sáenz de Santa María, geologist of HUNOSA, who knows the geology of the Central Coal Basin very well and who sampled the La Matinada-Los Nadales and La Inverniza-El Cabo sections.

\section{Locus typicus and stratum typicum}

La Matinada-Los Nadales section at some $4 \mathrm{~km}$ NE of Mieres, on the road from Mieres to Sama at the Santo Emilano Hill, Central Coal Basin (Fig. 1). Generalas Beds, gray mudstone, sample N13,M16, at $65 \mathrm{~m}$ above the base of the beds, i.e. above the La Torala Limestone (Leyva and Gervilla, 1983; Luque et al., 1985).

\section{Material}

Holotype (DPO 38146) incomplete specimen with both valves (Fig. 5a) and five other specimens from the type locality and horizon (DPO 38145, 38147), all with the shell preserved.

From the same section and also from the Generalas Beds, sample N-13,M-13 are some 10 specimens (DPO 38139$38144,38153-38154)$ and from sample N-13,M-17, 5 specimens (DPO 38148-38152); most of these specimens have their shell preserved but some are moulds. 


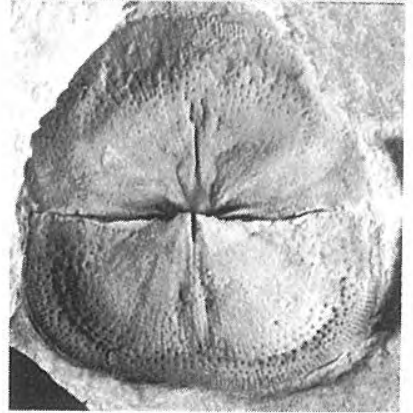

a

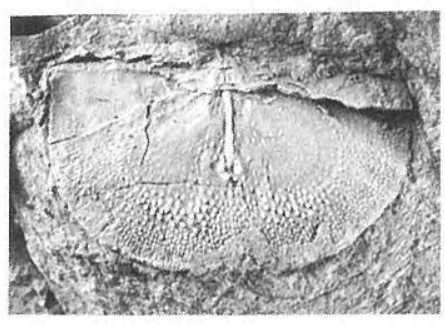

e

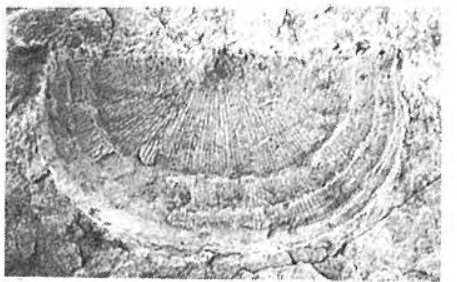

i

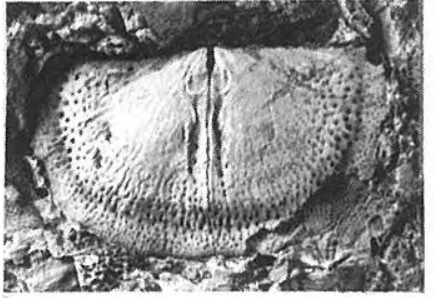

$\mathrm{m}$

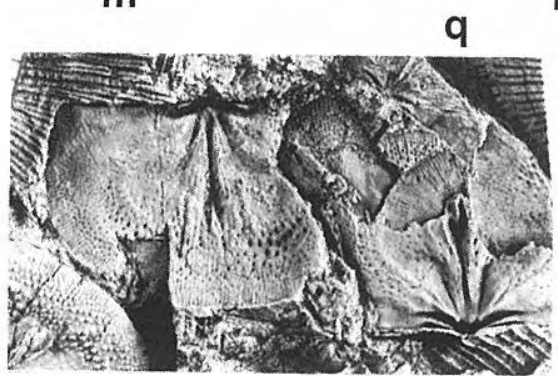

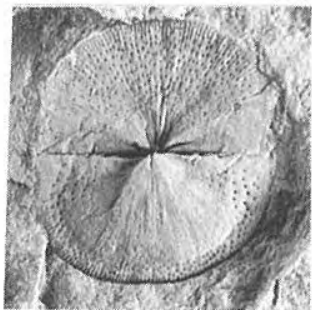

C

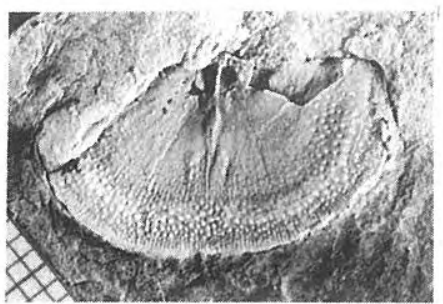

g

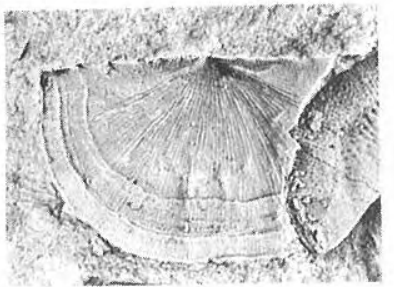

k

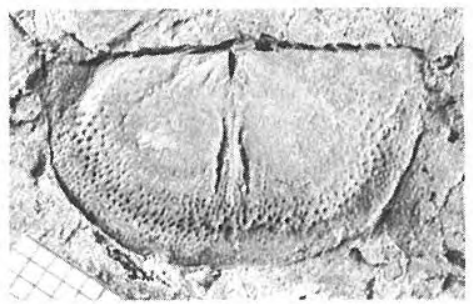

n

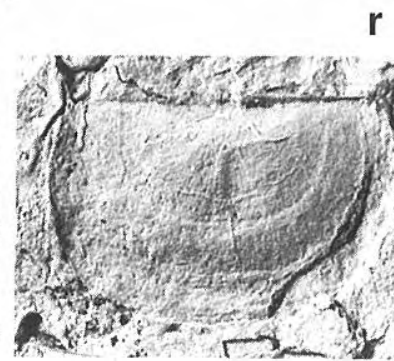

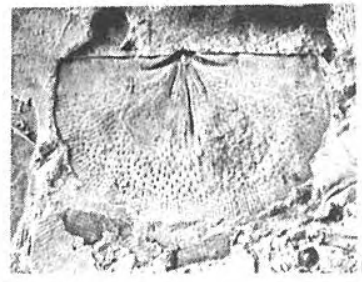

o

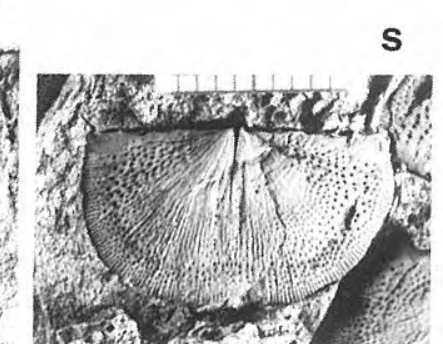

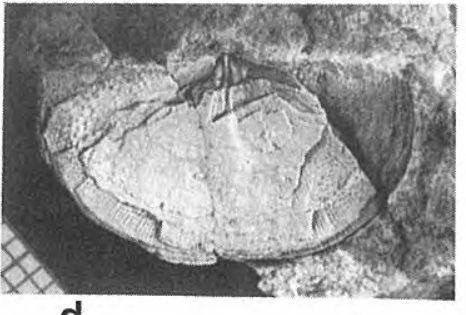

d

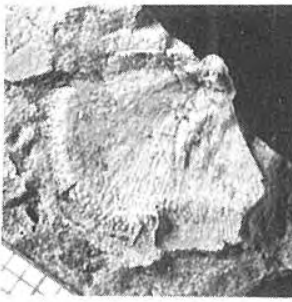

h

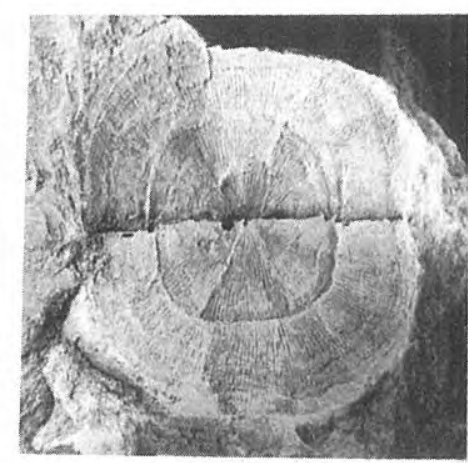

I

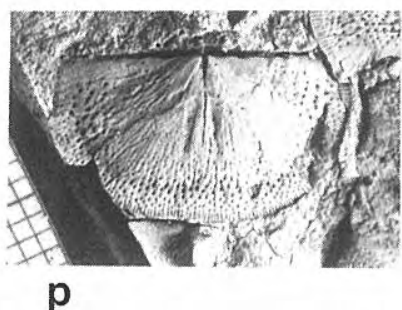

p

$\mathbf{t}$

Figure 3. Neochonetes (Neochonetes) villamaninensis sp. nov., railway cutting S of Villanueva de la Tercia (León), Villamanín Beds; all x 2. a. Holotype, DPO 38058, internal mould of both valves united at the hinge. b. DPO 38059, external mould of both valves united at the hinge; the dorsal one is incomplete. c. DPO 38060, juvenile specimen, internal mould of both valves united at the hinge. d. DPO 38061, damaged specimen, in ventral view, showing part of the dorsal interior and of the external moulds of the dorsal and ventral valves. e-f. DPO 38062, dorsal interior with part of the ventral valve preserved and mould of the same specimen. g. DPO 38063, ventral interior. h. DPO 38075 , fragmentary ventral interior. i. DPO 38073, external mould of ventral valve. j. DPO 38068, external mould of dorsal valve. k. DPO 38074, external mould of incomplete ventral valve. I. DPO 38072, external mould of both valves united at the hinge. m. DPO 38079, internal mould of ventral valve. n. DPO 38076, internal mould of ventral valve. o. DPO 38080, internal mould of dorsal valve. p. DPO 38066, internal mould of ventral valve. q. internal moulds of dorsal valves, DPO 38070 (at left) and DPO 38071 (incomplete, at right). r. DPO38077, ex.ternal mould of dorsal valve. s. DPO 38065, internal mould of ventral valve. t. DPO 38064, internal mould of ventral valve. 


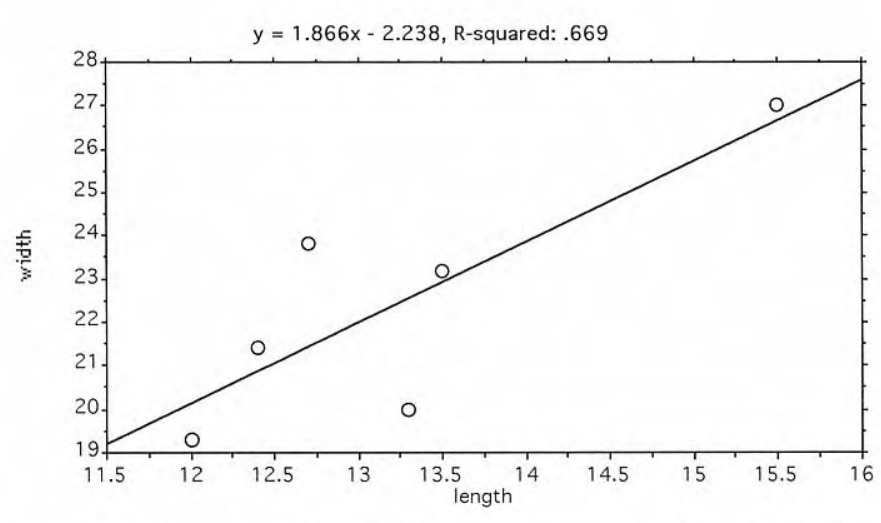

Figure 4. Length-width diagram of Neochonetes (Neochonetes) saenzi sp. nov.

About 10 moulds (some with a small part of the shell preserved) (DPO 38135-38138) from the San Antonio Beds, La Inverniza-El Cabo section, c. $10 \mathrm{~km} \mathrm{E}$ of Mieres (Fig. 1) (Leyva and Gervilla, 1983), sample C-12,M-1, are assigned to the species with some doubts.

\section{Diagnosis}

Medium-sized Neochonetes (Neochonetes) of the lineage of $N$. (N.) granulifer with the ventral valve weakly but regularly convex; hinge line equal to the greatest width or nearly so; sulcus and fold weakly developed or may even be absent; ornamentation of weak costae and costellae, c. 4 per $\mathrm{mm}$ in the anterior part; occasionally becoming obsolete towards the anterior margin. Ventral interior with poorly delimited muscular field and marginal rim. Dorsal interior with strong anderidia.

\section{Description}

Shell of medium size $[\mathrm{L}=12.0-15.5 \mathrm{~mm}$ (medium 13.2), $\mathrm{W}=19.3-27.0 \mathrm{~mm}$ (medium 22.7); dimensions of holotype: $\mathrm{L}$ $=15.5 \mathrm{~mm}, \mathrm{~W} \sim 27 \mathrm{~mm}$; Fig. 4], concavo-convex or planoconvex, transverse $(\mathrm{L} / \mathrm{W}=\mathrm{c} .0 .6)$, with rounded cardinal extremities and the maximum width at the hinge or just in front of it. Sulcus and fold weakly developed or absent.

Ventral valve weakly convex, with umbo hardly protruding. On both sides of the umbo 5 spines have been observed, forming a rather large angle with the hinge; ears hardly delimited. Costellate ornamentation with fine costae and costellae, occasionally disappearing towards the front, with 4 per $\mathrm{mm}$ in the anterior region; on the anterior third of the valve growth lamellae appear which become closer near the border.

Dorsal valve weakly concave or flat, with a similar ornamentation.

Ventral valve interior with a very high median septum in its posterior part; a pair of strong, parallel vascular ridges; muscle field poorly delimited; marginal rim. The internal surface, apart from the muscle scars, is covered with radially arranged rows of tubercles; those in front of the marginal rim are very fine and densely packed.

In the interior of the dorsal valve only the cardinal process, cardinal process pit, median septum, strong anderidia, and tubercles were observed.

\section{Comparison}

The new species is distinguished from $N$. (N.) villamaninensis and $N$. (N.) asturianus by its flattened shell and large size. Also, unlike $N$. (N.) villamaninensis, it normally has a sulcus, although weakly developed, and stronger anderidia.

A comparison with the new species $N$. (N.) asturianus and $N$. (N.) babianus follows below at the descriptions of those species.

Its flat shell and relatively large size compare well with $N$. dalmanoides (Nikitin, 1890), but the Russian species has normally small pointed ears, a distinct sulcus and fold, and is larger. Also, the costulation apparently continues to the front of the shell in $N$. dalmanoides.

\section{Distribution}

The species is known from Upper Moscovian strata of the Generalas Beds and possibly also the San Antonio Beds of the Central Coal Basin.

\section{Neochonetes (Neochonetes) asturianus sp. nov.} Figs. 6-7

\section{\pm 1985 Rugosochonetes cf. dalmanoides; Luque et al., 294 (pars).}

Derivatio nominis: From Latin asturianus, inhabitant of Asturias, the province from which our material has derived.

\section{Locus typicus and stratum typicum}

Section of the trail to the Navidiello Hill, some $4 \mathrm{~km} \mathrm{E}$ of Puente de los Fierros, Pontones syncline, Central Coal Basin (Fig. 1). Generalas Beds, sample N-6, at $6 \mathrm{~m}$ above the base of a $19 \mathrm{~m}$ thick lutite at the base of the section, Podolsky (Upper Moscovian).

\section{Material}

Holotype (DPO 38108) an internal mould of a ventral valve (Fig. 7a), and 25 specimens, external and internal moulds of one valve or the other from the type locality and horizon (DPO 38109-38126).

The remaining specimens are also from the Generalas Beds of Podolsky age in the Central Coal Basin: La Inverniza-El Cabo section at $10 \mathrm{~km} \mathrm{E}$ of Mieres (Leyva and Gervilla, 1983), sample L-9,M-4: 4 moulds (DPO 3812738130) and sample L-9,M-5: 5 moulds (DPO 38131-38134).

\section{Diagnosis}

Neochonetes (Neochonetes) of the lineage of $N$. (N.) carboniferus having a convex ventral valve with a strongly curved postero-median region and well delimited, flattened ears; hinge line equal to the greatest width or nearly so; sulcus and fold variably developed; ornamentation of fine, but distinct costae and costellae, 47 per $\mathrm{mm}$ at the anterior margin. Ventral interior with pronounced adductor scars, posteriorly limited by strong ridges; near the internal border there is an elevated rim. Dorsal interior with strong anderidia forming an angle of c. $50^{\circ}$. 


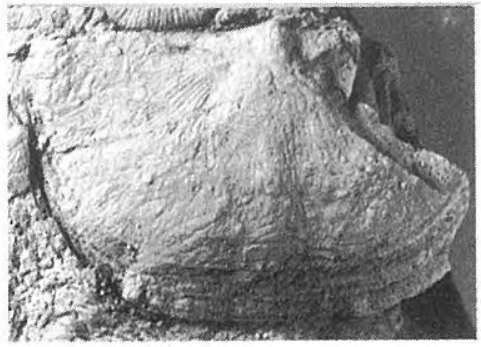

a

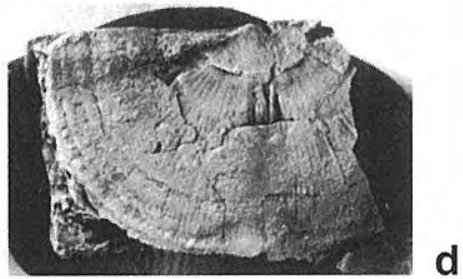

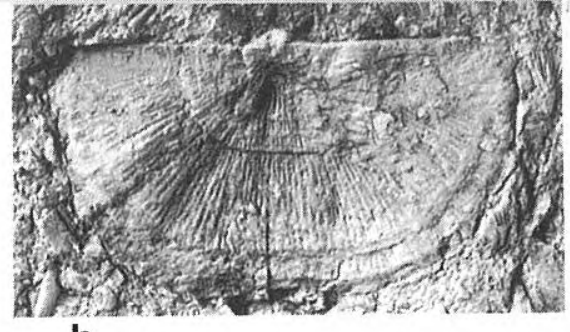

b

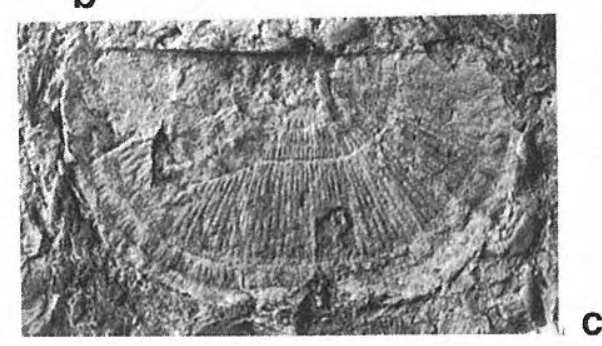

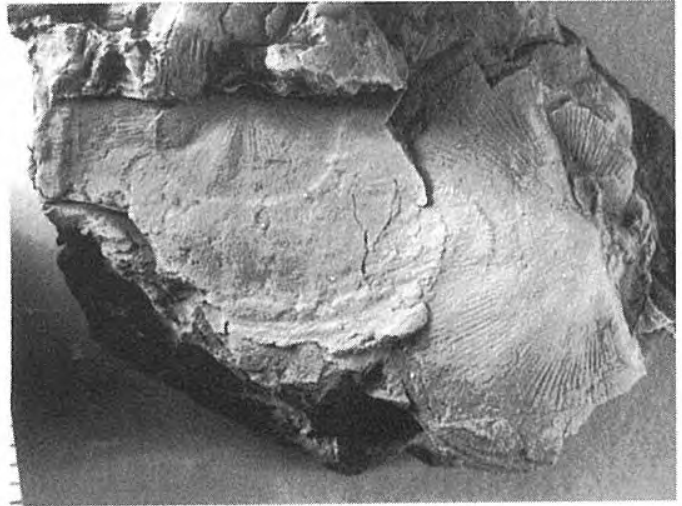

e

Figure 5. Neochonetes (Neochonetes) saenzi sp. nov. Central Coal Basin, La Matinada-Los Nadales section, Generalas Beds, Upper Moscovian (probably Podolsky); all x 2. a-c. Sample N-13:M-16. a. Holotype, DPO 38146, damaged specimen in ventral view. b-c. DPO 38145, dorsal valve exterior and external mould of the same. d-e. Sample N13:M-17. d. DPO 38148, incomplete specimen in ventral view, showing part of internal mould of ventral valve. e. DPO 38149, ventral view of a somewhat damaged specimen (at right), and DPO 38150, external mould of dorsal valve (at left).

\section{Description}

Shell of small to medium size $[\mathrm{L}=5.9-13.8 \mathrm{~mm}$ (medium 10.2), $\mathrm{W}=10.8-24.0 \mathrm{~mm}(\operatorname{medium~17.4})$; dimensions of holotype: $\mathrm{L}=10.3 \mathrm{~mm}, \mathrm{~W} \sim 19 \mathrm{~mm}$; Fig. 6], concavo-convex to plano-convex, transverse ( $\mathrm{L} / \mathrm{W}=$ c. 0.6 ), with rounded cardinal extremities and the maximum width at the hinge or just in front of it. Sulcus and fold variably developed.

Ventral valve convex, with an elevated postero-median region and well delimited, flattened ears. On both sides of the umbo up to 9 spine bases were counted. Costellate ornamentation with fine costae and costellae, with 4-7 per $\mathrm{mm}$ at the anterior border; on the anterior third of the valve some growth lamellae appear which are more closely spaced near the border.

Dorsal valve weakly concave or flat with a similar ornamentation.

Ventral valve interior with a high median septum in its posterior part between the adductor scars, continuing in front of them to mid length as a low ridge. Adductor scars small and oval, strongly impressed, and postero-laterally bordered by strong ridges; the diductor scars are large, flabelliform and poorly delimited. In front of the adductors originate a pair of strong vascular ridges, parallel to the median septum and close to it, which continue almost to the anterior margin. Close to the margin and parallel to it there is an elevated rim. The internal surface, apart from the muscle scars, is covered with tubercles; these are fine and densely packed near the front.

Interior of dorsal valve with bilobed cardinal process (externally tetralobate), separated from the median septum by a cardinal process pit. The median septum is strong and about half the valve length; at its anterior end normally two parallel rows of 2-3 elevated, thick tubercles occur.
Anderidia as strong as the median septum, diverging at an angle of c. $50^{\circ}$. Inner socket ridges elevated, forming a low angle with the hinge. Brachial ridges weakly developed. Internal surface, apart from the posterior central part, covered with tubercles.

\section{Comparison}

The new species resembles $N$. (N.) villamaninensis closely, but is distinguished by its more convex ventral valve with variably developed sulcus and better delimited ears, well separated from the remainder of the valve. There are also some internal differences, such as the ridges posterior to the adductors, which are more marked, and the more elevated anterior rim. The main differences in the dorsal interior are the stronger anderidia forming a larger angle in $N$. (N.) asturianus.

Our new species is distinguished from $N$. (N.) saenzi by its rather more convex ventral valve and ears that are well differentiated from the remainder of the valve.

A comparison with the new species $N$. (N.) babianus follows below at the description of that species.

The species has been previously identified as Rugosochonetes cf. dalmanoides (Nikitin, 1890) by one of us (M.L.M.Ch.). It is, however, differentiated from that species (now included in the genus Neochonetes) from the Upper Carboniferous of the Moscow Basin by its more convex ventral valve with better delimited ears, and by its smaller size.

\section{Distribution}

The species is only known from Upper Moscovian (Podolsky) strata of the Generalas Beds of the Central Coal Basin. 


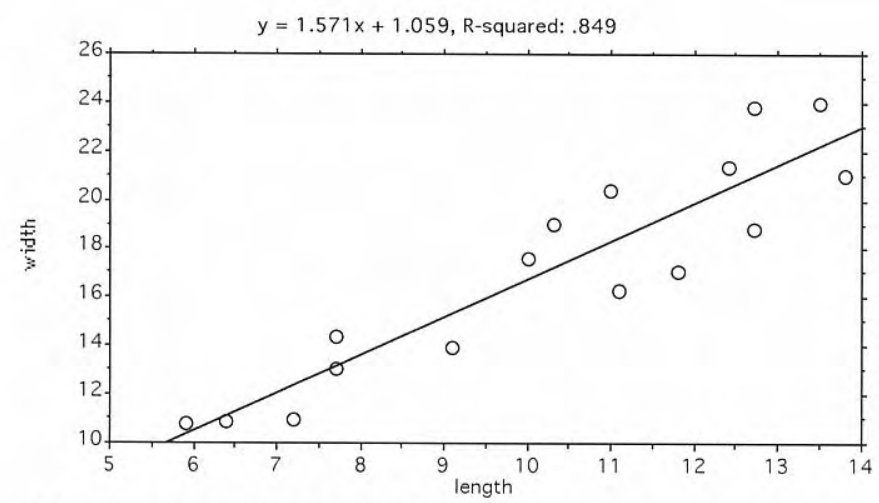

Figure 6. Length-width diagram of Neochonetes (Neochonetes) asturianus sp. nov.

\section{Neochonetes (Neochonetes) babianus sp. nov.}

1968 Neochonetes acanthophorus (Girty, 1934); Winkler Prins, 119, pl. 9: 11-16.

1977 Rugosochonetes acanthophorus (Girty); Martínez Chacón, 42.

1979 Rugosochonetes acanthophorus (Girty, 1934); Martínez Chacón, 91, pl. 7: 19-22, pl. 8: 1-9.

1985 Rugosochonetes acanthophorus (Girty, 1934); Martínez Chacón and Winkler Prins, 236, pl. 1: 1-2.

1990 Rugosochonetes acanthophorus (Girty, 1934); Martínez Chacón, 96, pl. 1: 19.

1993 Rugosochonetes acanthophorus; Martínez Chacón, in Sánchez de Posada et al., 94.

Derivatio nominis: From "babiano", inhabitant of the region La Babia (León), from which our material has derived.

\section{Locus typicus and stratum typicum}

Locality at the outskirts of San Emiliano on the road to La Majua, León province (Winkler Prins, 1968, loc. 20; Fig. 1). Basal part of the lowermost limestone of the La Majua Member of the San Emiliano Formation, of late Bashkirian age (cf. Wagner et al., 1983: fig. 20).

\section{Material}

Holotype (RGM 291437, Winkler Prins, 1968, pl. 9, fig. 11; a complete specimen) and many additional specimens from the type locality (cf. Winkler Prins, 1968; Martínez Chacón, 1979).

\section{Diagnosis}

Neochonetes (Neochonetes) of the lineage of $N$. (N.) carboniferus having a markedly convex ventral valve with small, poorly delimited ears; hinge line equal to the greatest width or nearly so; sulcus and fold variably developed; ornamentation of fine but prominent costae and costellae, 5-6 per $\mathrm{mm}$ at the anterior margin, growth lamellae and numerous scattered spinule apertures; 7 or 8 spines occur on each side of the umbo forming an angle of c. $50^{\circ}$ with the hinge. Ventral interior with pronounced adductor scars and moderately developed vascular ridges; surface covered with endospines, becoming very small near the anterior border. Dorsal interior with strong anderidia forming an angle of c. $40^{\circ}$.

\section{Description}

For a full description the reader is referred to previous papers of the authors cited in the synonymy, notably Winkler Prins (1968) and Martínez Chacón (1979, 1990).

\section{Comparison}

From the true $N$. (Neochonetes) acanthophorus (Girty, 1934), originally described as Chonetes granulifer var. armatus by Girty (1911; see also Dunbar and Condra, 1932) and to which our new species has been referred in the past, $N$. (N.) babianus is differentiated by its pronounced costulation, which does not become obsolete towards the anterior margin (see discussion of the subgenus above).

The new species is distinguished from $N$. (N.) villamaninensis by the presence of a variably developed sulcus and fold, its concave brachial valve, more pronounced costellation with numerous spinule apertures, and some internal differences, especially its less strongly developed vascular ridges.

From $N$. (N.) saenzi our new species is distinguished by its better developed sulcus and fold, its more concave brachial valve, and more pronounced costellation with numerous spinule apertures.

The new species is distinguished from $N$. (N.) asturianus by its less demarcated and weakly developed ears, its more concave brachial valve, more pronounced costellation with numerous spinule apertures, and its less strongly developed vascular ridges.

\section{Distribution}

The species is known from the San Emiliano Formation (Upper Bashkirian) of León, and the Levinco Beds of the Central Coal Basin and the Cuera Limestone (E Asturias) (Lower Moscovian: Vereisky).

\section{Subfamily Riosanetinae subfam. nov.}

Type genus: Riosanetes gen. nov.

\section{Diagnosis}

Small to medium-sized rugosochonetids with costellate ornamentation; oblique orthomorph spines. Dorsal interior without median septum.

\section{Genera included}

Apart from the type genus: Permochonetes Afanasjeva, 1977, Lower Permian of the Pamirs.

\section{Discussion}

The new subfamily is established to include in it the chonetids with an exterior like the representatives of the subfamily Rugosochonetinae, but without a dorsal median septum or traces of lateral septa.

The lophophore of the members of this subfamily is considered to have been schizolophe, as normally found in the Rugosochonetidae, and not ptycholophe as 


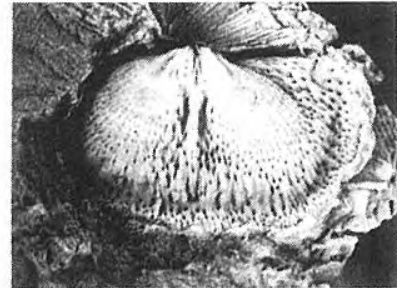

a

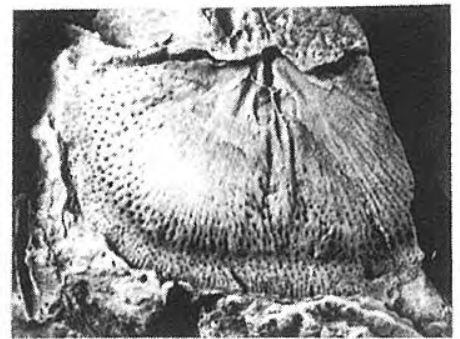

e

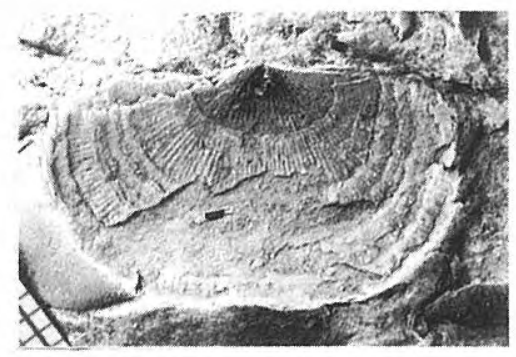

j

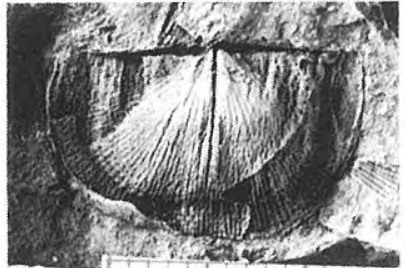

b

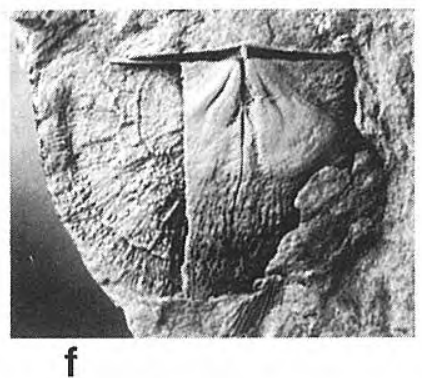

f

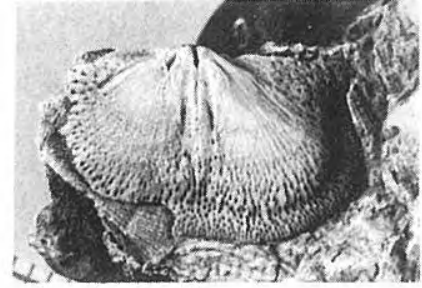

C

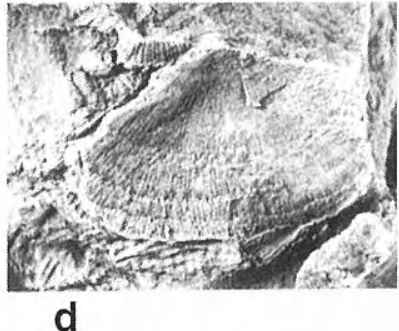

d

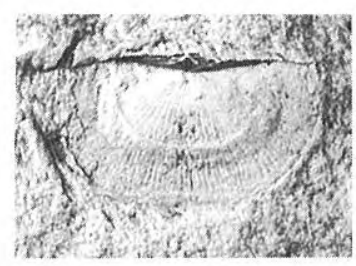

i

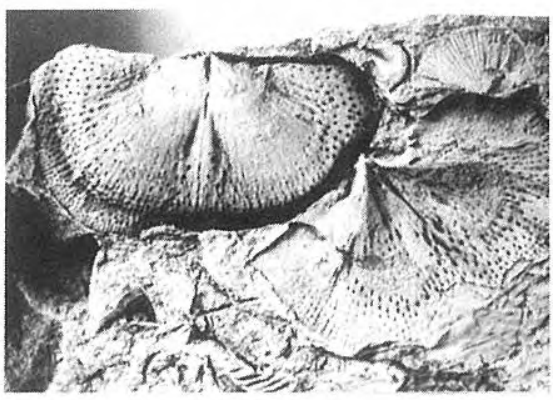

k

Figure 7. Neochonetes (Neochonetes) asturianus sp. nov. Central Coal Basin, Generalas Beds, Upper Moscovian (probably Podolsky); all x 2. a-g. Navidiello Hill (Puente de los Fierros), sample N-6. a. Holotype, DPO 38108, internal mould of ventral valve. b. DPO 38117, internal mould of ventral valve, less convex than usual. c-d. DPO 38119 , internal mould of ventral valve and fragment of the external mould. e. DPO 38121, internal mould of ventral valve. f. DPO 38115, damaged internal mould of ventral valve with part of dorsal external mould. g. DPO 38118, internal mould of dorsal valve. h-j. La Inverniza-El Cabo section, sample L-9:M-5. h-i. DPO 38133, external moulds of ventral and dorsal valves. j. DPO 38131, external mould of ventral valve. k. La Inverniza-El Cabo section, sample L-9:M-4, DPO 38127, internal mould of ventral valve (at left) and DPO 38128, internal mould of dorsal valve (at right).

considered typical for the Anopliidae (cf. Afanasjeva, 1984, fig. 2).

We have transferred the genus Permochonetes, formerly included in the family Anopliidae, to the Rugosochonetidae, and to the new subfamily in particular, because its form and ornamentation coincides with that of the Rugosochonetidae, it lacks a dorsal median septum and is considered to have had a schizolophe lophophore (cf. Afanasjeva, 1984, fig.3; 1988, fig. 48). In our view it seems unlikely that a schizolophe has developed from a ptycholophe, as suggested by Afanasjeva $(1984$, p. $101=92)$, since the former is a more primitive stage. Afanasjeva (1977) recognised that Permochonetes resembles Neochontes externally, from which it is distinguished by the absence of a median septum in the interior of the dorsal valve.

\section{Distribution}

Pennsylvanian (Upper Moscovian) of Asturias (N Spain) and Lower Permian of the Pamirs.
Genus Riosanetes gen. nov.

Derivatio nominis: After "Riosa", a region in Asturias from which the type species of the genus is derived, and "netes", termination of "Chonetes".

Type species: Riosanetes fernandezi gen. et sp. nov.

\section{Diagnosis}

Small, thin shell, plano-convex to slightly concavoconvex, with a subrectangular outline, cardinal extremities rounded; costellate ornamentation with fine costae and costellae, apart from the ears, which are smooth. Ornamentation internally as prominent as externally, suggesting a very thin shell. Ventral interior with a short median septum, posteriorly elevated; without vascular ridges. Dorsal interior with very thin anderidia, high and strong inner socket ridges, without median septum; tubercles placed in rows along the intercostal sulci, occasionally the tubercles of the central rows are 


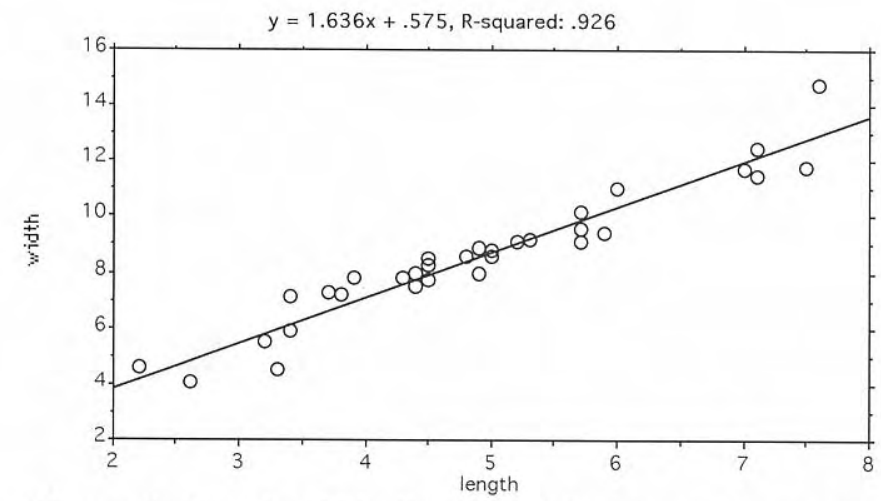

Figure 8. Length-width diagram of Riosanetes fernandezi gen. et sp. nov.

more marked, but they never form septa; brachial ridges not developed.

Species included: Type species only.

\section{Discussion}

The new genus is included in the family Rugosochonetidae because of its form, ornamentation and the characteristics of the ventral valve. The exterior is similar to the representatives of the subfamily Rugosochonetinae, but is distinguished from them, fundamentally, by the absence of a median septum in the dorsal interior. This lack of a dorsal median septum is what brought us to modify the diagnosis of the family to include the genus and to establish the new subfamily Riosanetinae.

The ornamentation and the interior of the dorsal valve are like those of Permochonetes, which we have included also in the new subfamily, but which is fundamentally differentiated from it by its ventral interior, the Permian genus having a much better developed muscular field and a pair of vascular ridges; besides, Permochonetes has a larger size and thicker shell.

Riosanetes resembles the Permian genus Fanichonetes Xu y Grant, 1994, a lot by its external characteristics and those of the ventral interior. The dorsal interior of Fanichonetes is poorly known, and therefore it is uncertain whether it has a median septum. If it is lacking, it should also be included in the new subfamily Riosanetinae.

Alatochonetes Liang, 1990 is another Permian genus, included in the subfamily Rugosochonetinae and which dorsal interior is poorly known. However, it is differentiated from Riosanetes by its ornamentation of thick costae crossed by strong rugae with prominent tubercles at the intersections. The ornamentation, by the way, makes it rather doubtful whether this genus belongs to the Chonetoidea, let alone the Rugosochonetidae. The figured material of the type species Alatochonetes alata (Liang, 1990, pl. 15, figs. 15-16) appears to be insufficiently preserved to decide this matter.

Arctochonetes Ifanova, 1968 has a poorly defined dorsal median septum, but, contrary to Riosanetes, has a pair of accessory septa (and thus cannot be included in the family Rugosochonetidae) and a pair of vascular truncs in the ventral interior.

The form, ornamentation and the caracteristics of the ventral interior of Riosanetes suggest the genus Rugosochonetes Sokolskaja, 1950, from which it is differentiated by the lack of a median septum in the dorsal interior.

The new genus resembles Caenanoplia Carter, 1968 (Family Anopliidae, Subfamily Caenanopliinae) by its lack of a median septum and accessory septa in the dorsal interior, but Caenanoplia is clearly differentiated by its form and ornamentation, which is very distinct from that of the Rugosochonetidae.

Subglobosochonetes Afanasjeva, 1976 resembles the new genus in having a well developed costellate ornamentation, though not as strongly developed as in

Figure 9. Riosanetes fernandezi gen. et sp. nov.; all x 2.5, except a, which is x 5. a-p. Villamerí, Riosa (Asturias), sample Ri-3, Canales Fm., Upper Moscovian. a. Holotype, DPO 38155, internal mould of dorsal valve. b. Holotype, DPO 38155 , external mould of dorsal valve (lower left) and DPO38158, internal mould of dorsal valve (upper right). c. DPO 38158, external mould of dorsal valve. d-e. Two moulds of ventral valves (the larger, DPO38163) both external and internal. f. Internal mould of ventral valve (DPO 38156, upper right), external mould of dorsal valve (DPO38161, lower right), external mould of ventral valve (center) and external mould of dorsal valve (DPO 38184, left). g. Countermould of specimes shown in f: dorsal interior (DPO 38184), ventral interior, ventral exterior (DPO 38156 ) and dorsal interior somewhat eroded (DPO 38161). h. Two external moulds of dorsal valves, DPO 38159 (lower) and DPO 38160 (upper left). i. Internal moulds of the preceding specimens. j. External mould of dorsal valve, DPO 38162 (upper part of foto), and internal mould of dorsal valve (lower right) and external mould of dorsal valve (lower left) of two other specimens. k. Countermoulds of preceding specimens. 1. DPO 38177, internal mould of ventral valve. m-n. DPO 38178, external and internal moulds of ventral valve. o. Moulds of various specimens with part of the shell preserved; e.g. DPO 38176, internal mould of ventral valve (at left) and dorsal interior with high internal crests (bottom center). p. DPO38157, internal mould of ventral valve. q-s. Candemuela (León), sample T296, Candemuela Member of the San Emiliano Fm., Lower Moscovian. q-r. DPO 38196, dorsal exterior, somewhat decorticated, showing part of the internal mould, and external mould of the same specimen with part of the interior of the dorsal valve. s. DPO38194, internal mould of dorsal valve (lower part of foto) and DPO 38195, external mould of ventral (upper part). t-u. Mieres, probably Caleras Beds, Upper Moscovian. t. DPO 38185, internal mould of both valves united at the hinge. u. DPO 38186, internal mould of both valves united at the hinge. v. La MatinadaLos Nadales section, sample N-13:M-16, Generalas Beds, Upper Moscovian. DPO 38192, external mould of both valves united at the hinge. 
Riosanetes, and in lacking a median septum, but it shows traces of lateral septa in the form of weak ridges in the brachial valve interior and thus in our view is rightly included in the subfamily Caenanopliinae of the Anopliidae.

\section{Distribution}

Moscovian of Asturias and León.
Riosanetes fernandezi gen. et sp. nov.

Figs. 8-9

Derivatio nominis: The species is dedicated to Dr Luis Pedro Fernández González (Geology Department, University of Oviedo), who studied the Carboniferous stratigraphy of the Riosa area.

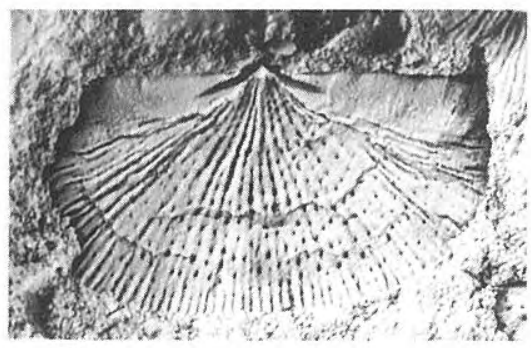

a

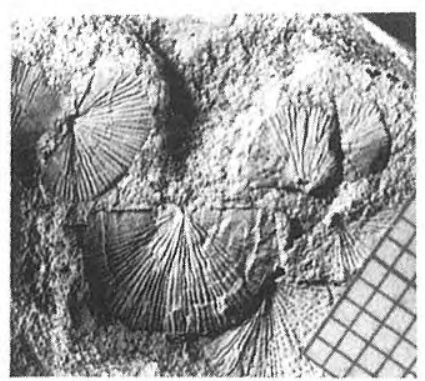

h

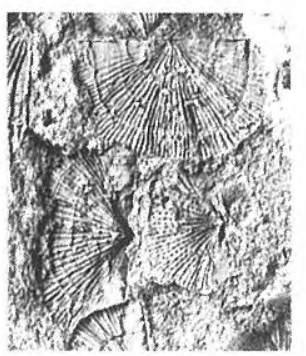

j

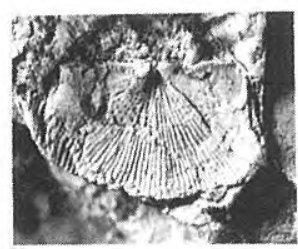

q

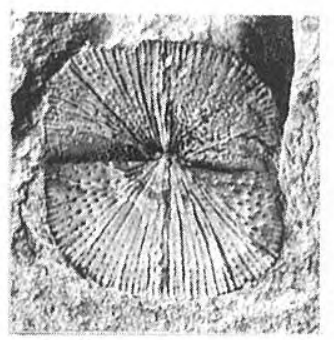

t
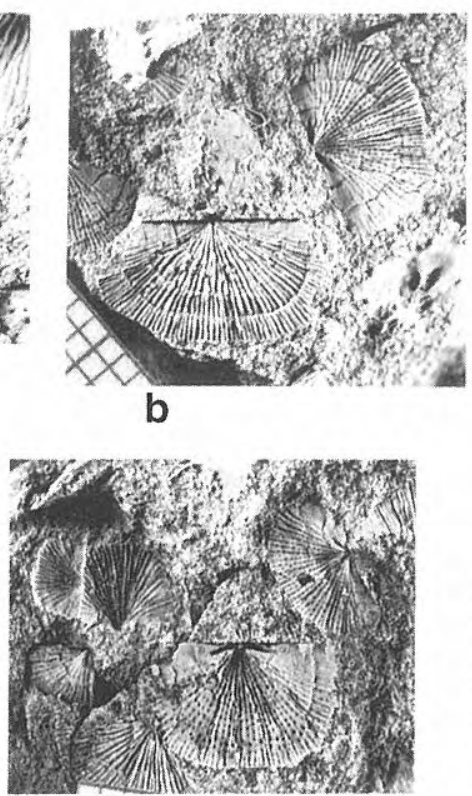

i
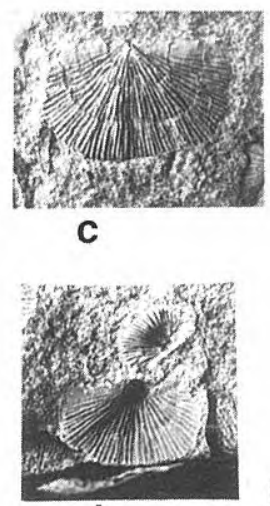

d

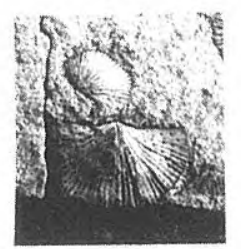

e
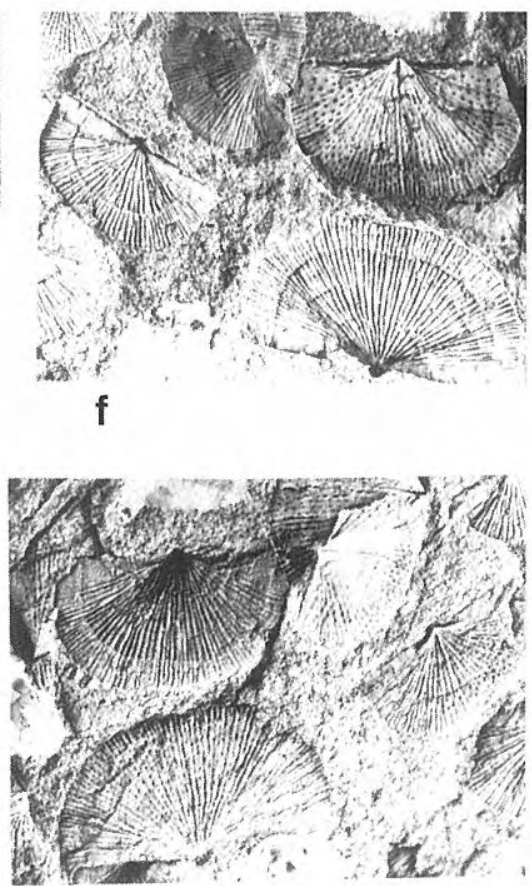

g

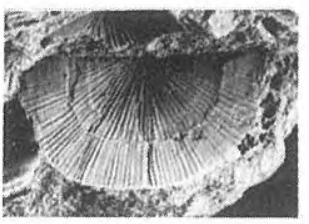

m

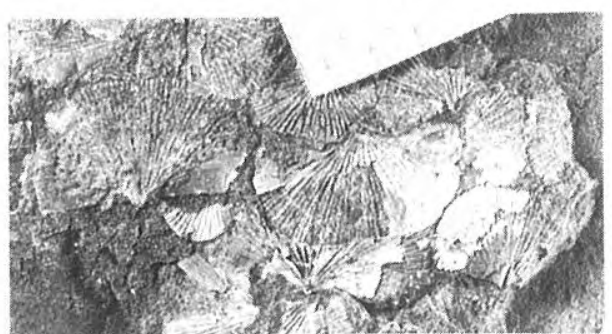

o

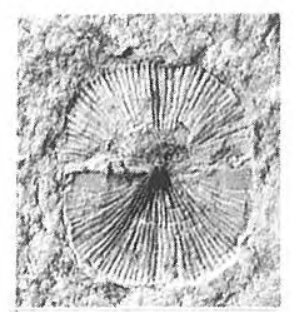

v

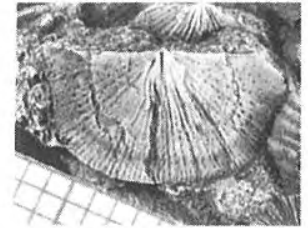

n

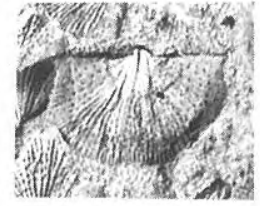

p

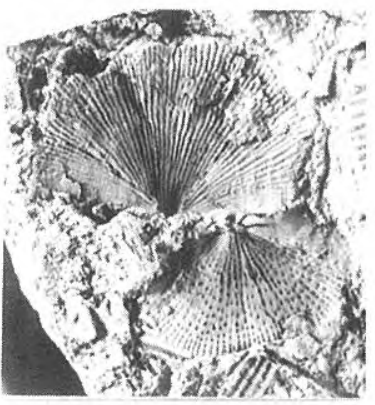

S 


\section{Locus typicus and stratum typicum}

Upper trail from Villamerí, Riosa. Canales Formation (Upper Moscovian), sample Ri-3, mudstones from bed 19 of the log "Montsacro 2 (superior)" of Fernández González (1990), some $6.5 \mathrm{~m}$ above a covered part.

\section{Material}

Holotype (DPO 38155) internal and external mould of a dorsal valve (Fig. 9a-b), and some 40 additional specimens (DPO 38156-38184, 38187-38190), some with their shell preserved, but the majority are external or internal moulds of one valve or the other, originated from the type locality and layer.

La Matinada-Los Nadales section at some $4 \mathrm{~km} \mathrm{NE}$ of Mieres, on the road from Mieres to Sama by the Santo Emilano Hill, Central Coal Basin (Fig. 1). Generalas Beds, gray mudstone bed, sample N13,M16, at $65 \mathrm{~m}$ above the base, i.e. above the La Torala Limestone, some 30 specimens, some with their shell preserved, others as moulds (DPO 38191-38193).

$\mathrm{S}$ of Mieres, on the road to Rozaes de Bazuelo (Central Coal Basin), probably Caleras Beds, 2 internal moulds of both valves united at the hinge (DPO 38185-38186).

$\mathrm{W}$ of Candemuela (León), mudstone $100 \mathrm{~m}$ below the top of the Candemuela Member of the San Emiliano Formation (Carballeira et al., 1985), Lower Moscovian, sample T-296, 4 moulds, some with their shell preserved (DPO 38194-38197).

\section{Diagnosis}

As for the genus.

\section{Description}

Very thin, small shell $[\mathrm{L}=2.2-7.6 \mathrm{~mm}$ (medium 4.9 ), $\mathrm{W}$ $=4.1-14.8$ (medium 8.7); dimensions of the holotype: $\mathrm{Ld}=$ 5.2; $\mathrm{W}=10.5$; see Fig. 9], plano-convex or weakly concavo-convex, transverse $(\mathrm{L} / \mathrm{W}=0.5-0.7)$, with a subrectangular to semi-elliptic outline, cardinal extremities rounded, the maximum width coinciding with the hinge or slightly in front of it. Sulcus and fold absent or only slightly developed.

Ventral valve weakly convex, with a small beak slightly curved over the interarea. On each side of the umbo a maximum of 6 spine bases is observed; the angle of the spines with the hinge could not be observed. Ornamentation costellate, except on the ears, which are smooth, at least in the posterior part; costae and costellae thin, numbering 1518 at $3 \mathrm{~mm}$ width at the anterior margin; they multiply by bifurcation.

Dorsal valve flat or slightly concave, less curved than the ventral one; with a similar ornamentation.

Interior of ventral valve with short median septum, posteriorly elevated; ornamentation the reverse of the exterior, with tubercles placed in rows along the external intercostal sulci. In mature specimens, a weak rim can be observed near the margin (Fig. 9n,p).

Interior of dorsal valve with deep cardinal process pit; internal socket ridges strong, straight and short, forming an angle of c. $20^{\circ}$ with the hinge; anderidia very thin, no median septum; ornamentation as in the ventral valve; some specimens with more marked tubercles on the central rows, but without forming a septum.

\section{Comparison}

Externally, the species resembles the species of Rugosochonetes found in the Cantabrian Mts in strata of the same age (see Winkler Prins, 1968; Martínez Chacón, 1979), especially $R$. skipseyi (Currie, 1937, in Currie et $a l$.). It is mainly differentiated by the absence of a dorsal median septum. Also, Riosanetes fernandezi is less transverse than Rugosochonetes skipseyi.

\section{Distribution}

The species is known from the Canales Fm. (Riosa, Asturias) and the Generalas Beds and probably also from the Caleras Beds (Central Coal Basin), Upper Moscovian; also from the Candemuela Member of the San Emiliano Fm. (Candemuela, León), Lower Moscovian.

\section{ACKNOWLEDGEMENTS}

We like to thank the referees Drs M. Legrand née Blain (Bordeaux University) and E. Villas (Zaragoza University) for their critical comments which have greatly improved the manuscript. We are also much indepted to $\mathrm{Mr}$ J. Vázquez Varela (Oviedo University) for taking the photographs.

The first author (M.L.M.Ch.) acknowledges financial support from the project PB 98-1550 (Dirección General de Enseñanza Superior e Investigación Científica y Técnica). This paper is a contribution to PICG project 421.

\section{REFERENCES}

Afanasjeva, G.A. 1976. Chonetacea (Brachiopoda) rannego Karbona Ruskoy Platformy. Paleontologichesky Zhurnal, 1976(3), 58-70, pl. 5 (in Russian; English transl.: Early Carboniferous Chonetacea (Brachiopoda) of the Russian Platform. Paleontological Journal, 1976, 299-309).

Afanasjeva, G.A. 1977. Permochonetes gen. nov. (Brachiopoda) iz Nizhney Permi Pamira. Paleontologichesky Zhurnal, 1977(1), 147-151 (in Russian; English transl.: Permochonetes gen. nov. (Brachiopoda) from the Lower Permian of the Pamirs. Paleontological Journal, 1977, 138-141).

Afanasjeva, G.A. 1984. K sistematike brakhiopod semejstva Anopliidae. Paleontologichesky Zhurnal, 1984(1), 98102 (in Russian; English transl.: Brachiopod systematics of the family Anopliidae. Paleontological Journal, 1984, 89-93).

Afanasjeva, G.A. 1988. Brakhiopody otradya Chonetida (istoricheskoe razvitie, funktsionalnaya morfologiya, filogenez i sistema). Trudy Paleontologicheskogo Instituta, Akademiya Nauk SSSR, 228, 123 pp. (in Russian).

Amerom, H.W.J. van, Bless, M.J.M. and Winkler Prins, C.F. 1970. Some paleontological and stratigraphical aspects of the Upper Carboniferous Sama Formation (Asturias, 
Spain). Mededelingen Rijks Geologische Dienst, N.S., 21, 9-79.

Archbold, N.W. 1981. Studies on Western Australian Permian brachiopods. 2. The family Rugosochonetidae Muir-Wood, 1962. Proceedings of the Royal Society of Victoria, 93(2), 109-128.

Archbold, N.W. 1982a. Classification and evolution of the brachiopod family Rugosochonetidae Muir-Wood, 1962. Proceedings of the Royal Society of Victoria, 94(1), 1-9.

Archbold, N.W. 1982b. Sommeriella, a new name for the Permian chonetacean brachiopod subgenus Sommeria Archbold 1981. Proceedings of the Royal Society of Victoria, 94(1), 10.

Barrois, Ch. 1882. Recherches sur les terrains anciens des Asturies et de la Galice. Mémoire de la Société Géologique du Nord, 2(1), 1-630, 20 pls.

Carballeira, J., Corrales, I., Valladares, I., Naval, A., Ruiz, F., Lorenzo, S., Martínez Chacón, M.L., Méndez, C., Sánchez de Posada, L.C. y Truyols, J. 1985. Aportaciones al conocimiento de la estratigrafía de la Formación San Emiliano (Carbonífero, Cordillera Cantábrica) en su área tipo. Compte Rendu X Congrès International de Stratigraphie et de Géologie du Carbonifère, Madrid, 1983, 1, 345-362.

Carter, J.L. 1968. New genera and species of Early Mississipian brachiopods from the Burlington Limestone. Journal of Paleontology, 42, 1140-1152.

Currie, E.D., Duncan, C. and Muir-Wood, H.M. 1937. The fauna of Skipsey's Marine Band. Transactions of the Geological Society of Glasgow, 19, 413-452, pls. 2-4.

Delépine, G. 1943. Les faunes marines du Carbonifère des Asturies (Espagne). Mémoires de l'Académie des Sciences de l'Institut de France, 66(3), 122 pp., 6 pls.

Demanet, F. et Straelen, V. van 1938. Faune houillière de la Belgique. In: Renier, A., Stockmans, F., Demanet, F. et Straelen, V. van. Flore et faune houillières de la Belgique. Patrimoine du Musée royal d’Histoire naturel de Belgique, Bruxelles, 99-246, pls. 106-144.

Dunbar, C.O. and Condra, G.E. 1932. Brachiopoda of the Pennsylvanian System in Nebraska. Nebraska Geological Survey, Bulletin, $2^{\text {nd }}$ Series, 5, 377 pp., 44 pls.

Fernández González, L.P. 1990. Estratigrafía, sedimentología y paleogeografía de la región de Riosa, Quirós y Teverga-San Emiliano. Doctor's Thesis, Departamento de Geología, Universidad de Oviedo, 322 pp., appendices (unpublished).

Girty, G.H. 1911. On some new genera and species of Pennsylvanian fossils from the Wewoka formation of Oklahoma. Annals of the New York Academy of Sciences, 21, 119-156.

Girty, G.H. 1934. Pleurotomaria pseudostrigillata nom. nov. and Chonetes acanthophorus nom. nov. Journal of the Washington Academy of Sciences, 24, 541.

Ifanova, V.V. 1968. Nekotorye rannepermskie Chonetidae Pechorskogo basseyna. Paleontologichesky Zhurnal, 1968(3), 29-33, pl. 4 (in Russian; English transl.: Early Permian Chonetidae from the Pechora Basin. Paleontological Journal, 1968, 318-322, pl. 4).

Keyserling, A., 1846, Wissenschaftliche Beobachtungen auf einer Reise in das Petschora-Land im Jahre 1843. Geognostische Beobachtungen. I. Palaeontologische Bemerkungen. St Petersburg, 151-336, pls. 1-22.

King, R.H. 1938. New Chonetidae and Productidae from Pennsylvanian and Permian strata of north-central Texas. Journal of Paleontology, 12, 257-279, pls. 36-39.

Leyva, F. y Gervilla, M. (Co-Dirs.) 1983. Libro Guía de la Excursión W. El Carbonífero Medio de la Cuenca Central Asturiana y zonas adyacentes. X ICC, Madrid, 1983, E.N. Adaro de Investigaciones Mineras, 200 pp.

Liang Wenping 1990. Lengwu Formation of Permian and its brachiopod fauna in Zhejiang Province. People's Republic of China Ministry of Geology and Mineral Resources, Geological Memoirs, series 2, 10, 522 pp., 84 pls.

Luque, C., Gervilla, M., Sáenz de Santa María, J.A., Leyva, F., Laveine, J.P., Loboziak, S. y Martínez Chacón, M.L. 1985. Características sedimentológicas y paleontológicas de los paquetes productivos en el corte de La InvernizaEl Cabo (Cuenca Central Asturiana). Compte Rendu X Congrès International de Stratigraphie et de Géologie du Carbonifère, Madrid, 1983, 1, 281-302.

Martínez Chacón, M.L., 1977. Contenido en braquiópodos (Orthida, Strophomenida y Rhynchonellida) de algunas formaciones del Carbonífero cantábrico. Breviora Geológica Astúrica, 21, 41-48.

Martínez Chacón, M.L. 1979. Braquiópodos carboníferos de la Cordillera Cantábrica (Orthida, Strophomenida y Rhynchonellida). Memorias del Instituto Geológico y Minero de España, 96, 291 pp., 32 pls.

Martínez Chacón, M.L. 1990. Braquiópodos carboníferos de la costa E de Asturias (España). I. Orthida, Strophomenida, Rhynchonellida y Athyridida. Revista Española de Paleontología, 5, 91-110.

Martínez Chacón, M.L. and Winkler Prins, C.F. 1985. The brachiopod fauna of the San Emiliano Formation (Cantabrian Mountains, NW Spain) and its connection with other areas. Compte Rendu IX Congrès International de Stratigraphie et de Géologie du Carbonifère, Washington \& Champaign-Urbana, 1979, 5 (Paleontology, Paleoecology, Paleogeography), 233-244, 2 pls.

Moore, L.R., Neves, R., Wagner, R.H. and Wagner-Gentis, C.H.T. 1971. The stratigraphy of Namurian and Westphalian rocks in the Villamanín area of northern León, N.W. Spain. In: The Carboniferous of Northwest Spain, I. (Ed. R.H. Wagner). Trabajos de Geología, Universidad de Oviedo, 3, 307-363.

Muir-Wood, H.M. 1962. On the morphology and classification of the suborder Chonetoidea. British Museum (Natural History), London, $132 \mathrm{pp}$.

Owen, D.D. 1852. Report of a Geological Survey of Wisconsin, Iowa and Minnesota and incidentally of a portion of Nebraska Territory. Lippincott, Grambo \& Co, Philadelphia, xxxviii +638 pp., 14 pls.

Nikitin, S. 1890. Dépôts carbonifères et puits artésiens dans la région de Moscou. Mémoire du Comité géologique de St Pétersbourg, 5(5), 1-182, 5 pls.

Pérez-Estaún, A., Bastida, F., Alonso, J.L., Marquínez, J., Aller, J., Álvarez Marrón, J., Marcos, A. and Pulgar, J.A. 
1988. A thin-skinned tectonics model for an arcuate fold and thrust belt: the Cantabrian Zone. Tectonics, 7, 517537.

Racheboeuf, P.R. 1998. The chonetoidean brachiopods. A revised and updated systematic and bibliographic catalogue. Documents des Laboratoires de Géologie Lyon, 148, 178 pp.

Río García, L.M. 1993. Braquiópodos de los paquetes improductivos de la Cuenca Carbonífera Central (Asturias, $N$ de España). Doctor's Thesis, Universidad de Oviedo, 260 pp., 9 pls. (unpublished).

Río García, L.M. y Martínez Chacón, M.L. 1988. Braquiópodos moscovienses del Paquete Levinco (Cuenca Carbonífera Central de Asturias). Trabajos de Geología, Universidad de Oviedo, 17, 33-56.

Sánchez de Posada, L.C., Martínez Chacón, M.L., Méndez, C.A., Ménendez Álvarez, J.R., Truyols, J., and Villa, E., 1993. El Carbonífero de las regiones de Picos de Europa y Manto del Ponga (Zona Cantábrica, $\mathrm{N}$ de España): fauna y bioestratigrafía. Revista Española de Paleontología, no. extr., 89-108.

Sokolskaja, A.N. 1950. Chonetidae Russkoy Platformy. Trudy Paleontologicheskogo Instituta, Akademiya Nauk SSSR, 27, 107 pp., 13 pls (in Russian).

Villa, E., Horvath, V., Martínez Chacón, M.L. y Sánchez de Posada, L.C. 1988. Datos paleontológicos y edad de la sección deVillamanín (Carbonífero, C. Cantábrica, NW de España). Comunicaciones II Congreso Geológico de España, 1, 337-341.

Wagner, R.H. and Winkler Prins, C.F. 1985. The Cantabrian and Barruelian stratotypes: a summary of basin development and biostratigraphic information. In: Papers on the Carboniferous of the Iberian Peninsula (Sedimentology, Stratigraphy, Palaeontology, Tectonics and Geochronology) (Eds. M.J. Lemos de Sousa \& R.H. Wagner). Anais da Faculdade de Ciências, Supp. vol. 64 (1983) Special volume in honour of Wenceslau de Lima, palaeobotanist and statesman (1858-1919), 359-410.

Wagner, R.H., Martínez García, E., Winkler Prins, C.F. and Lobato, L. (Co-Dirs.) 1983. Guidebook of Fieldtrip A: Carboniferous stratigraphy of the Cantabrian Mountains. X ICC, Madrid, 1983, E.N. Adaro de Investigaciones Mineras, $209 \mathrm{pp}$.

Williams, A. and Brunton, C.H.C. 1997. Morphological and anatomical terms applied to brachiopods. In: Treatise on Invertebrate Paleontology. Part H. Brachiopoda. Revised. Vol. 1. Introduction (Ed. R.L. Kaesler). The Geological Society of America, Inc. \& The University of Kansas, Boulder \& Lawrence, 423-440.

Winkler Prins, C.F. 1968. Carboniferous Productidina and Chonetidina of the Cantabrian Mountains (NW Spain): Systematics, stratigraphy and palaeoecology. Leidse Geologische Mededelingen, 43, 41-126, 8 tab., 9 pls.

Winkler Prins, C.F. 1983. A general review of the Carboniferous brachiopods from the Cantabrian Mountains (North Spain). In: Contributions to the Carboniferous Geology and Palaeontology of the Iberian Peninsula (Ed. M.J. Lemos de Sousa). Universidade do Porto, Faculdade de Ciências, Porto, 69-91.

$\mathrm{Xu}, \mathrm{G}$. and Grant, R.E. 1994. Brachiopods near the PermianTriassic boundary in South China. Smithsonian Contributions to Paleobiology, 76, 68 pp. 